University of Nebraska - Lincoln

DigitalCommons@University of Nebraska - Lincoln

$11-15-2014$

\title{
Performance of a Temperate-Zone Channel Catfish Biofloc Technology Production System During Winter
}

Bartholomew W. Green

bart.green@usda.gov

Follow this and additional works at: https://digitalcommons.unl.edu/usdaarsfacpub

Part of the Agriculture Commons, and the Aquaculture and Fisheries Commons

Green, Bartholomew W., "Performance of a Temperate-Zone Channel Catfish Biofloc Technology Production System During Winter" (2014). Publications from USDA-ARS / UNL Faculty. 2468.

https://digitalcommons.unl.edu/usdaarsfacpub/2468

This Article is brought to you for free and open access by the U.S. Department of Agriculture: Agricultural Research Service, Lincoln, Nebraska at DigitalCommons@University of Nebraska - Lincoln. It has been accepted for inclusion in Publications from USDA-ARS / UNL Faculty by an authorized administrator of DigitalCommons@University of Nebraska - Lincoln. 


\title{
Performance of a temperate-zone channel catfish biofloc technology production system during winter
}

\author{
Bartholomew W. Green* \\ United States Department of Agriculture, Agricultural Research Service, Harry K. Dupree Stuttgart National Aquaculture Research Center, \\ Post Office Box 1050, Stuttgart, AR 72160, USA
}

\section{A R T I C L E I N F O}

\section{Article history:}

Received 12 September 2014

Accepted 7 November 2014

Available online 15 November 2014

\section{Keywords:}

Biofloc technology

Channel catfish

Low temperature

Ammonia

Biotransformation

\begin{abstract}
A B S T R A C T
Channel catfish (Ictalurus punctatus) have been grown successfully in an outdoor biofloc technology production system. Outdoor biofloc production systems in the tropics are operated year-round, whereas the channel catfish studies were conducted only during the growing season and biofloc production tanks were harvested and idled for the winter. If an outdoor biofloc production system is to be adopted by farmers at temperate latitudes, then data gaps related to system and fish performance over the winter must be addressed. The present study was conducted to address these data gaps for channel catfish culture. Waters from a recently completed biofloc production experiment that contained low $(153.3 \mathrm{mg} / \mathrm{L})$ and high $(790.0 \mathrm{mg} / \mathrm{L})$ total suspended solids were retained for this study. Three $15.7-\mathrm{m}^{3}$ tanks per water type each were stocked $\left(8 \mathrm{~kg} / \mathrm{m}^{3}\right)$ with market size channel catfish from that same study for a 152-day study from November to April. Mean chlorophyll a concentrations were similar in both treatments during the first 55 days, after which treatments diverged and chlorophyll a concentration increased linearly $\left(P<0.001, R^{2}=0.721\right)$ to a mean final concentration of $2251.7 \mathrm{mg} / \mathrm{m}^{3}$ in the low solids treatment. Ammonia from ammonium chloride spikes (1.25-1.5 mg TAN) added on three occasions during the experiment was biotransformed completely, putatively by algal uptake and nitrification. Ammonia biotransformation rate was linearly related to mean water temperature in the high solids $\left(P<0.001, R^{2}=0.920\right)$ and low solids $\left(P=0.002, R^{2}=0.761\right)$ treatments. Catfish survival through the winter was high $(99.75 \%)$ in biofloc tanks and did not differ significantly between treatments. Net fish yield did not differ significantly between treatments. However, net fish yields were 1-4\% less than initial fish biomasses. Water in the biofloc production tanks appeared to retain through the winter the ability to biotransform ammonia regardless of whether phytoplankton or suspended solids predominate and despite sustained input of ammonianitrogen. Having an active biofloc in the spring obviates the start-up time required to establish a new, fully functional biofloc and the associated TAN and nitrite spikes.
\end{abstract}

Published by Elsevier B.V.

\section{Introduction}

The biofloc technology (BFT) production system results in high yields of aquatic animals because two important productionlimiting factors, dissolved oxygen and total ammonia-nitrogen concentrations, are maintained at near-optimal levels despite high stocking and feeding rates (Avnimelech, 1999; Burford et al., 2004; Hargreaves, 2006). High dissolved oxygen concentration is maintained by continuous aeration, which also maintains the biofloc suspended in the water column. The biofloc is a complex of living organisms closely associated with particulate organic matter.

\footnotetext{
* Tel.: +1 870673 4483; fax: +1 8706737710 .

E-mail address: bart.green@ars.usda.gov
}

Nitrogenous waste excreted by the intensively fed culture animals utilized by phytoplankton and bacteria, which are part of this complex of living organisms.

Stocker-size and market-size channel catfish (Ictalurus punctatus) were grown successfully in an outdoor BFT production system and a net yield as high as $9.3 \mathrm{~kg} / \mathrm{m}^{3}$ was reported (Green, 2010; Schrader et al., 2011; Green et al., 2014). Unlike outdoor BFT production systems in the tropics that are operated year-round, the channel catfish studies were conducted only during the temperatezone growing season and BFT production tanks were drained and idled at harvest. Operating the BFT system only during the growing season implies that at harvest the fish must be marketable or of a size appropriate for a subsequent stage of grow out. Otherwise, fish will be moved unnecessarily. Additionally, 4-6 weeks are required at spring start-up for a fully functional biofloc to develop. 
If an outdoor BFT production system is to be adopted by farmers at temperate latitudes, then data gaps related to system and fish performance over the winter must be addressed.

Pond production of channel catfish requires that fish be overwintered at least once before being harvested as food fish. Survival of fish to harvest is good and generally exceeds $75 \%$ (Robinson and Li, 2008; Li et al., 2009). Recommendations for winter feeding of channel catfish vary feeding rates based on threshold water temperatures (Robinson et al., 2001). Gains or losses in individual fish weight and net yield can depend on the winter feeding strategy used, and fish size and survival (Lovell and Sirikul, 1974; Tackett et al., 1987; Tidwell and Mims, 1991; Burtle and Newton, 1993; Nanninga et al., 2011; Bastola et al., 2012).

The waters used for this experiment were retained from a just-completed freshwater BFT experiment that evaluated different levels of solids control; retained waters had high or low total suspended solids (TSS) concentrations. High TSS concentration in BFT can affect negatively culture animal performance and removal of solids to $200-400 \mathrm{mg} / \mathrm{L}$ TSS is recommended (Ray et al., 2010; Green et al., 2014). Furthermore, the retained waters used in the present experiment themselves will be retained for a follow-on study to evaluate re-use of BFT water during a second growing season. The objectives of the present experiment were to quantify changes in water quality and ammonia biotransformation capacity and channel catfish performance throughout the winter.

\section{Materials and methods}

\subsection{Biofloc technology production system}

Six wood-framed rectangular tanks with a slightly sloped bottom tanks $\left(18.6 \mathrm{~m}^{2}\right.$, mean $15.7 \mathrm{~m}^{3}$ of water, mean depth of $0.81 \mathrm{~m}$ ) lined with high density polyethylene (HDPE) located outdoors at the USDA Agricultural Research Service (ARS), Harry K. Dupree Stuttgart National Aquaculture Research Center (HKDSNARC), Stuttgart, AR, USA, were used for this study. One $2.6-\mathrm{kW}$ blower per three tanks provided air (ca. $295 \mathrm{~m}^{3} / \mathrm{h}$ ) continuously through a diffuser grid ( $\operatorname{six} 5.95 \mathrm{~m} \times 2.5 \mathrm{~cm}$ polyvinyl chloride pipes with $1.9-\mathrm{mm}$ diameter holes drilled at $15-\mathrm{cm}$ intervals) on the bottom of each tank. Waters from a BFT production experiment testing different levels of solids removal that concluded 14-15 November 2013 and contained low $(153.3 \pm 39.5 \mathrm{mg} / \mathrm{L}$, mean $\pm \mathrm{SE})$ or high $(790.0 \pm 48.4 \mathrm{mg} / \mathrm{L})$ TSS were retained for this study. Each tank required about $10 \%$ well water to complete filling. Triplicate tanks each were assigned randomly to the low and high TSS concentrations. Solids were not removed from tanks during this study.

\subsection{Water quality}

Initial water samples for this study were collected and analyzed 6 days after stocking. Water samples were collected from each tank on average at 2 week intervals at approximately $0830 \mathrm{~h}$. Total ammonia-nitrogen (TAN) was analyzed fluorometrically using the 0 -phthaldialdehyde method in a flow injection system (Genfa and Dasgupta, 1989). Nitrite-nitrogen $\left(\mathrm{NO}_{2}-\mathrm{N}\right.$, diazotization), nitrate-nitrogen $\left(\mathrm{NO}_{3}-\mathrm{N}\right.$, cadmium reduction), and soluble reactive phosphorus (ascorbic acid method) were analyzed using flow injection analysis according to manufacturer instructions (FIAlab 2500; FIAlab Instruments, Bellevue, Washington). Total alkalinity and total suspended solids were measured using the methods of Eaton et al. (2005). Chlorophyll $a$ was extracted in 2:1 chloroform:methanol from phytoplankton (for this study, "phytoplankton" includes planktonic algae and cyanobacteria as well as those attached to bioflocs) previously filtered from water samples by using a $0.45-\mu \mathrm{m}$ pore size glass fiber filter, and the chlorophyll a concentration in the extract was determined by spectroscopy (Lloyd and Tucker, 1988). Sample pH was measured electrometrically.

Dissolved oxygen (DO) concentration and water temperature in each tank were monitored continuously by a galvanic oxygen sensor (Type III, Oxyguard, Birkerød, Denmark) and a thermistor (Model 109, Campbell Scientific, Logan, Utah) connected to a datalogger (Model CR206 or CR10X, Campbell Scientific, Logan, Utah). Air temperature data was obtained from the weather station located within $0.5 \mathrm{~km}$ at USDA ARS Dale Bumpers National Rice Research Center, Stuttgart, Arkansas.

Stock salt $\left(144 \mathrm{~g} / \mathrm{m}^{3}\right)$ was added to each tank to ensure chloride concentration exceeded $100 \mathrm{mg} / \mathrm{L}$. Sodium bicarbonate $\left(72 \mathrm{~g} / \mathrm{m}^{3}\right)$ was added once (day 123) only to high solids treatment tanks to maintain pH values between 7.0 and 7.8 and total alkalinity about $100 \mathrm{mg} / \mathrm{L}$ as $\mathrm{CaCO}_{3}$.

\subsection{Ammonium chloride additions}

Ammonium chloride (untreated technical grade, 99.9\%, The Dallas Group of America, Whitehouse, New Jersey) was added to each tank on three occasions to measure TAN biotransformation over time. Dry matter content of ammonium chloride was 99.6\%. Each tank was dosed with ammonium chloride, on a dry matter basis, to add $1.5 \mathrm{mg} / \mathrm{L}$ TAN (16 December 2013), and $1.25 \mathrm{mg} / \mathrm{L} \mathrm{TAN} \mathrm{(27}$ January 2014; 10 March 2014). The quantity of TAN added was high enough to be detectable, but unlikely to be detrimental to the catfish (Hargreaves and Kucuk, 2001). Water samples were collected from each tank at 0 min, 15-60 min, 4 h (10 March only), 7-8 h, 24 h, 48 h, 72 h, 96 h, and 173 h (27 January 2014 only) after TAN addition and analyzed for TAN and $\mathrm{NO}_{2}-\mathrm{N}$; samples were analyzed for $\mathrm{NO}_{3}-\mathrm{N}$ at the beginning and end of each spike event.

\subsection{Catfish stocking, feeding, and harvesting}

Channel catfish (I. punctatus) harvested from the BFT production experiment were re-stocked into tanks. Mean biomass at stocking was $7.8 \pm 0.2$ and $8.2 \pm 0.5 \mathrm{~kg} / \mathrm{m}^{3}$ for the low and high solids treatments, respectively, and did not differ significantly between treatments $(P=0.490)$. Mean initial weight did not differ significantly between treatments and averaged $560.8 \pm 5.8$ and $611.3 \pm 22.9 \mathrm{~g} /$ fish for the low and high solids treatments, respectively. Fish in each tank were fed as much 32\% protein feed (Delta Western Feed Mill, Indianola, Mississippi) as they could consume in 10 min once the afternoon water temperature exceeded $16^{\circ} \mathrm{C}$ for two consecutive days, and the quantity recorded. Fish were harvested from all tanks on 16 April 2014, 152 days after stocking. At harvest, $25 \%$ of fish in each tank were weighed individually and the remainder were counted and weighed in bulk. Animal care and experimental protocols were approved by the HKDSNARC Institutional Animal Care and Use Committee and conformed to ARS Policies and Procedures 130.4 and 635.1.

\subsection{Data analysis}

Data were analyzed by mixed models analysis of variance (MIXED) and linear regression (REG) procedures in SAS v. 9.3. Initial TSS concentration was the fixed effect. The repeated measures mixed models procedure (MIXED) was used to compare slopes of ammonia-nitrogen transformation over time between treatments for each spike event; first-order ante dependence covariance structure was used for the first two spike events, and spatial power covariance structure was used for the third spike event (Littell et al., 2006). 

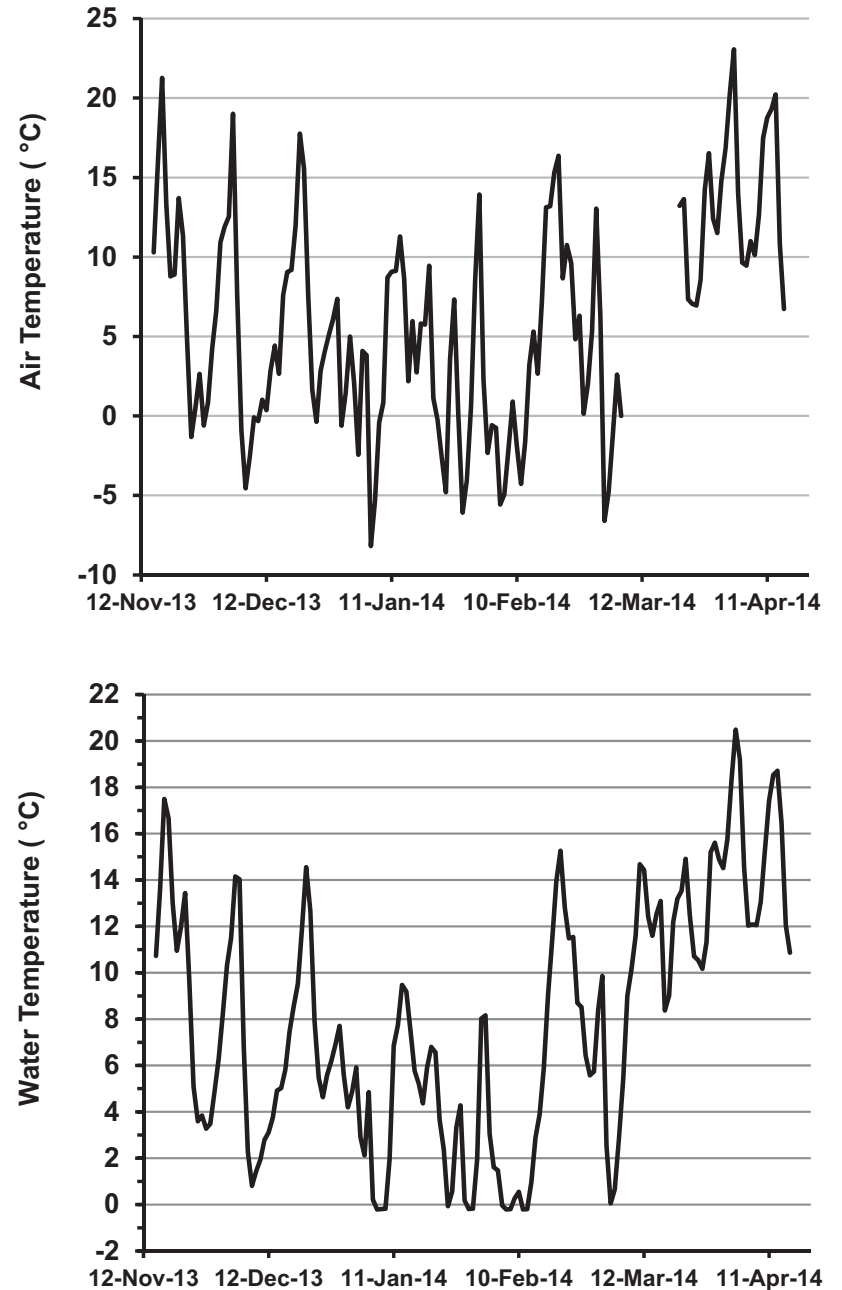

Fig. 1. Mean air (top) and biofloc tank water (bottom) temperatures from 15 November 2013 through 16 April 2014. The gap in air temperature data was caused by datalogger malfunction. Note that different scales on the $y$-axes are used for clarity.

\section{Results and discussion}

\subsection{Water quality}

Mean air temperature less than $0^{\circ} \mathrm{C}$ was recorded on 31 day, whereas mean water temperature was less than $0^{\circ} \mathrm{C}$ on 11 day and averaged $-0.6^{\circ} \mathrm{C}$ (Fig. 1). Water temperature did not differ significantly between treatments $(P=0.824)$ and the grand mean $( \pm \mathrm{SD})$ was $7.9 \pm 0.2{ }^{\circ} \mathrm{C}$. Mean daily dissolved oxygen concentration did not differ significantly between treatments $(P=0.681)$, and averaged $11.7 \pm 1.6 \mathrm{mg} / \mathrm{L}$. Ice, covering up to a maximum of about $75 \%$ of the tank surface, was observed on tanks during the coldest temperatures.

Water used for this study was retained from a just completed BFT study and was strongly nitrifying. Initial means did not differ significantly between low and high solids treatments, respectively, for TAN $(0.01 \pm 0.00$ and $0.00 \pm 0.00 \mathrm{mg} / \mathrm{L}, P=0.083), \mathrm{NO}_{2}-\mathrm{N}$ $(0.26 \pm 0.08$ and $0.01 \pm 0.08 \mathrm{mg} / \mathrm{L}, P=0.100), \mathrm{NO}_{3}-\mathrm{N}(71.03 \pm 9.88$ and $95.22 \pm 9.88 \mathrm{mg} / \mathrm{L}, P=0.159)$, total alkalinity $(132.0 \pm 23.5$ and $176.6 \pm 23.5 \mathrm{mg} / \mathrm{L}$ as $\left.\mathrm{CaCO}_{3}, P=0.252\right), \mathrm{pH}(8.2 \pm 0.0$ and $8.1 \pm 0.0$, $P=0.483)$, and chlorophyll $a\left(493.5 \pm 29.3\right.$ and $409.7 \pm 29.3 \mathrm{mg} / \mathrm{m}^{3}$, $P=0.113)$. Mean initial $\mathrm{PO}_{4}-\mathrm{P}$ concentration was significantly greater $(P=0.005)$ in the high solids $(33.1 \pm 1.6 \mathrm{mg} / \mathrm{L})$ than in the low solids $(20.3 \pm 1.6 \mathrm{mg} / \mathrm{L})$ treatment. Initial TSS in the high solids treatment $(790.0 \pm 48.4 \mathrm{mg} / \mathrm{L})$ was significantly greater $(P=0.002)$ than in the low solids treatment $(153.3 \pm 39.5 \mathrm{mg} / \mathrm{L})$.

No significant differences were detected between solids levels for mean TAN, $\mathrm{NO}_{2}-\mathrm{N}$, and total alkalinity concentrations (Table 1). Although mean $\mathrm{NO}_{3}-\mathrm{N}$ concentration in the high solids treatment was $43 \%$ higher than in the low solids treatment, the difference was not statistically significant at the 0.05 level $(P=0.062)$. Other treatment differences were significantly greater $\mathrm{PO}_{4}$-P and TSS concentrations in the high solids treatment, and significantly greater chlorophyll $a$ concentration and $\mathrm{pH}$ in the low solids treatment (Table 1). Water quality treatment means likely were not affected by feed addition because the same low quantity of feed was added to each treatment (see Section 3.3).

Changes in water quality variable concentrations during the experiment were different for each treatment. Mean TAN was significantly lower, and total alkalinity and $\mathrm{pH}$ were significantly greater in final compared to initial samples in the high solids treatment (Table 2). However, in the low solids treatment, mean final $\mathrm{NO}_{2}-\mathrm{N}$, TSS, and chlorophyll a concentrations were significantly greater than mean initial concentrations, and mean final concentrations of $\mathrm{NO}_{3}-\mathrm{N}$, soluble reactive phosphorus, total alkalinity, and $\mathrm{pH}$ were significantly lower than initial concentrations (Table 2). Total alkalinity decreased linearly throughout the experiment in the low solids treatment $\left(P<0.001, R^{2}=0.700\right)$ and through day 123 in the high solids treatment $\left(P<0.001, R^{2}=0.853\right)$; sodium bicarbonate $\left(72 \mathrm{~g} / \mathrm{m}^{3}\right)$ was added to high solids treatment tanks on day 123 following alkalinity measurement. During the first 70 days, $\mathrm{pH}$ in the low solids treatment was relatively constant and averaged $8.1 \pm 0.1$, but then decreased linearly beginning day $83(P<0.001$, $\left.R^{2}=0.770\right)$. In the high solids treatment, $\mathrm{pH}$ decreased linearly $\left(P<0.001, R^{2}=0.678\right)$ until day 123 when sodium bicarbonate was applied.

Mean TSS concentration in the high solids treatment remained above $300 \mathrm{mg} / \mathrm{L}$ and water retained its brown color throughout the study (Fig. 2). In the low solids treatment, mean TSS concentration remained around $200 \mathrm{mg} / \mathrm{L}$ through day 123 , after which it increased slowly to $403.3 \mathrm{mg} / \mathrm{L}$ by day 151 . The recommended range of TSS for channel catfish is $282-427 \mathrm{mg} / \mathrm{L}$ (Green et al., 2014). Mean chlorophyll a concentrations were similar in both treatments during the first 55 days, after which treatments diverged and chlorophyll a concentration increased linearly $(P<0.001$, $R^{2}=0.721$ ) to a mean final concentration of $2251.7 \mathrm{mg} / \mathrm{m}^{3}$ in the low solids treatment (Fig. 2). The low solids concentration allowed sunlight to penetrate deeper into the water column, which stimulated algal growth. Similarly high chlorophyll $a$ concentrations were reported during the summer and fall in a channel catfish BFT production system (Schrader et al., 2011).

\subsection{Ammonia transformation}

Mean TAN concentration was less than $0.4 \mathrm{mg} / \mathrm{L}$ TAN except after ammonium chloride was added to tanks (Fig. 3). Total ammonia-nitrogen concentration peaked following ammonium chloride addition and then declined as ammonia-nitrogen was transformed. No significant treatment difference $(P=0.240)$ in slope was detected for ammonia transformation during the first spike event. Regression equations were $y=1.719-0.016 x$ $\left(R^{2}=0.944\right)$ and $y=2.208-0.018 x\left(R^{2}=0.893\right)$ for the low and high solids treatments, respectively, where $y=\operatorname{mg} /$ L TAN and $x=h$. During the second spike event, ammonia transformation slope was significantly greater $(P=0.048)$ in the high solids treatment. Ammonia transformation was described by regression equations, $y=1.204-0.003 x\left(R^{2}=0.560\right)$ and $y=1.500-0.005 x\left(R^{2}=0.749\right)$ for the low and high solids treatments, respectively. Slope of ammonia transformation did not differ significantly $(P=0.096)$ between treatments during the third spike event. Low and high solids 
Table 1

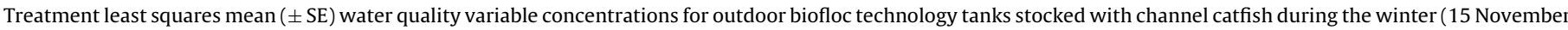
2013 to 16 April 2014). Treatments were high and low initial concentrations of total suspended solids (TSS) in tank waters.

\begin{tabular}{|c|c|c|c|c|}
\hline \multirow[t]{2}{*}{ Variable } & \multicolumn{2}{|c|}{ Initial TSS concentration } & \multirow{2}{*}{$\begin{array}{l}\text { Pooled } \\
\text { SE }\end{array}$} & \multirow[b]{2}{*}{$\operatorname{Pr}>F$} \\
\hline & High & Low & & \\
\hline Total ammonia-nitrogen (mg/L) & 0.16 & 0.20 & 0.03 & 0.292 \\
\hline Nitrite-nitrogen (mg/L) & 0.38 & 0.33 & 0.05 & 0.528 \\
\hline Nitrate-nitrogen $(\mathrm{mg} / \mathrm{L})$ & 93.44 & 65.32 & 7.75 & 0.062 \\
\hline Soluble reactive phosphorus (mg/L) & 29.80 & 17.52 & 1.44 & 0.004 \\
\hline Chlorophyll $a\left(\mathrm{mg} / \mathrm{m}^{3}\right)$ & 378.2 & 1178.1 & 48.8 & $<0.001$ \\
\hline Total suspended solids (mg/L) & 659.5 & 205.6 & 23.5 & $<0.001$ \\
\hline Total alkalinity $\left(\mathrm{mg} / \mathrm{L}\right.$ as $\left.\mathrm{CaCO}_{3}\right)$ & 102.2 & 98.1 & 5.2 & 0.600 \\
\hline $\mathrm{pH}$ & 7.78 & 7.98 & 0.04 & 0.031 \\
\hline
\end{tabular}

Table 2

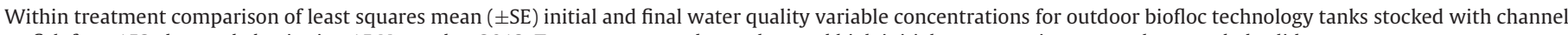
catfish for a 152-day study beginning 15 November 2013. Treatments tested were low and high initial concentrations to total suspended solids.

\begin{tabular}{|c|c|c|c|c|c|c|c|c|}
\hline Treatment & $\mathrm{NH}_{4}-\mathrm{N}^{\mathrm{a}}$ & $\mathrm{NO}_{2}-\mathrm{N}^{\mathrm{a}}$ & $\mathrm{NO}_{3}-\mathrm{N}^{\mathrm{a}}$ & $\mathrm{PO}_{4}-\mathrm{P}^{\mathrm{a}}$ & Chl $a^{\mathrm{a}}$ & TSS $^{\mathrm{a}}$ & $\mathrm{T} \mathrm{Alk}^{\mathrm{a}}$ & $\mathrm{pH}$ \\
\hline \multicolumn{9}{|l|}{ Low solids } \\
\hline Initial & 0.01 & 0.26 & 70.97 & 20.34 & 493.5 & 153.3 & 132.0 & 8.19 \\
\hline Final & 0.08 & 0.90 & 58.18 & 14.01 & 2251.7 & 403.3 & 67.7 & 7.59 \\
\hline Pooled SE & 0.03 & 0.11 & 6.89 & 1.41 & 369.6 & 11.8 & 16.8 & 0.03 \\
\hline $\operatorname{Pr}>F$ & 0.119 & 0.016 & 0.041 & 0.034 & 0.077 & 0.002 & 0.089 & 0.004 \\
\hline \multicolumn{9}{|l|}{ High solids } \\
\hline Initial & 0.00 & 0.01 & 95.18 & 33.08 & 409.7 & 606.7 & 176.6 & 8.14 \\
\hline Final & 0.04 & 0.14 & 90.51 & 28.67 & 541.6 & 687.8 & 91.6 & 7.59 \\
\hline Pooled SE & 0.01 & 0.06 & 8.97 & 2.43 & 65.6 & 140.9 & 18.2 & 0.08 \\
\hline $\operatorname{Pr}>F$ & 0.046 & 0.173 & 0.685 & 0.185 & 0.091 & 0.705 & 0.030 & 0.010 \\
\hline
\end{tabular}

a Total ammonia-nitrogen $\left(\mathrm{mg} / \mathrm{L} \mathrm{NH}_{4}-\mathrm{N}\right)$, nitrite-nitrogen $\left(\mathrm{mg} / \mathrm{L} \mathrm{NO}_{2}-\mathrm{N}\right)$, nitrate-nitrogen $\left(\mathrm{mg} / \mathrm{L} \mathrm{NO}_{3}-\mathrm{N}\right)$, soluble reactive phosphorus (mg/L PO 4 -P), chlorophyll $a\left(\mathrm{mg} / \mathrm{m}^{3}\right.$ $\mathrm{Chl} a$ ), total suspended solids ( $\mathrm{mg} / \mathrm{L} \mathrm{TSS})$, total alkalinity ( $\mathrm{mg} / \mathrm{L}$ as $\left.\mathrm{CaCO}_{3} \mathrm{~T} \mathrm{Alk}\right)$.

treatment regression equations were $y=1.129-0.016 x\left(R^{2}=0.934\right)$ and $y=1.111-0.025 x\left(R^{2}=0.890\right)$, respectively.

Ammonia transformation rate (slope absolute value) within treatment appeared to be affected by the mean water temperature during each ammonium chloride spike event (Fig. 4). The increase in ammonia transformation rate as mean water temperature increased from spike event 1 to 2 was similar for both treatments. However, no further increase in ammonia transformation rate was
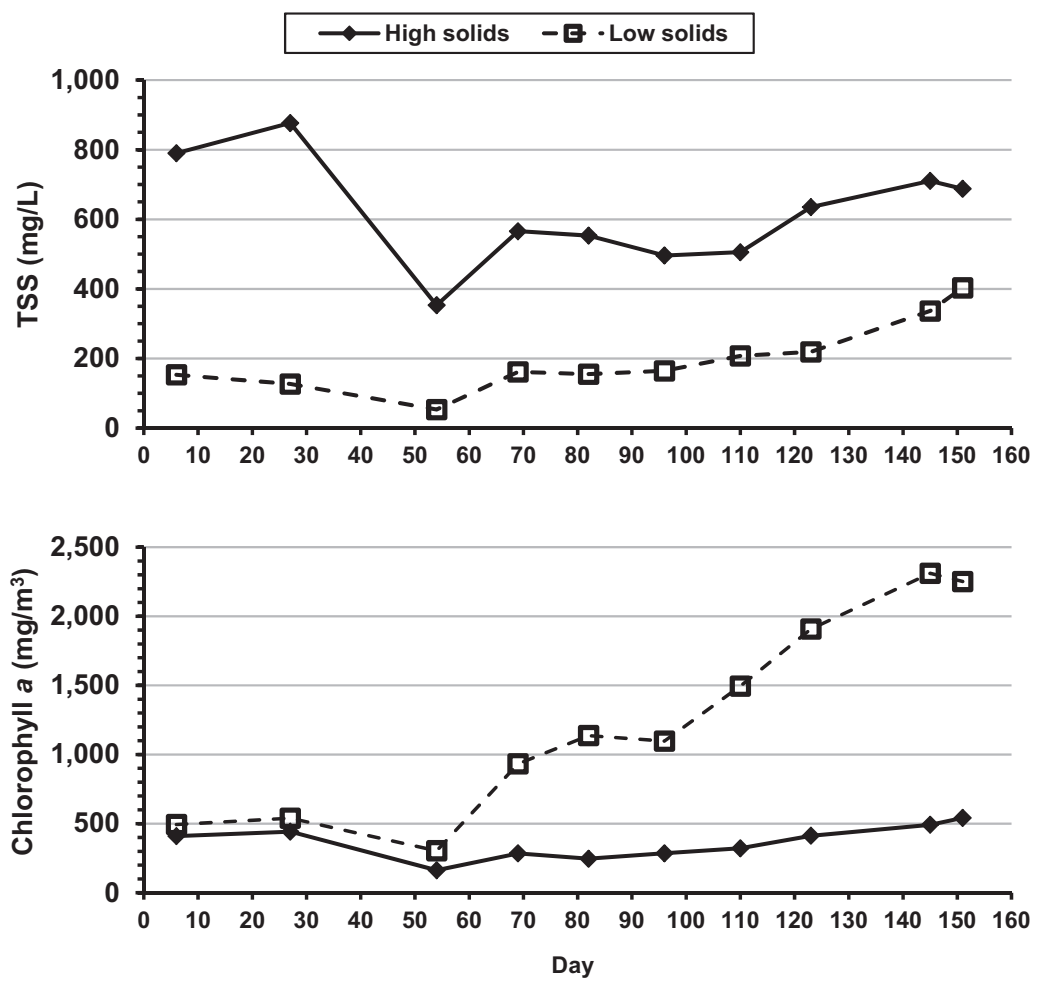

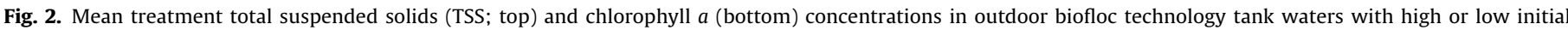

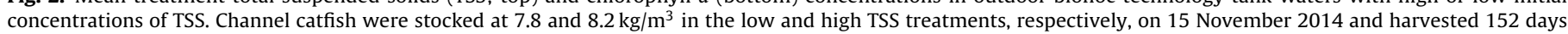
later. 

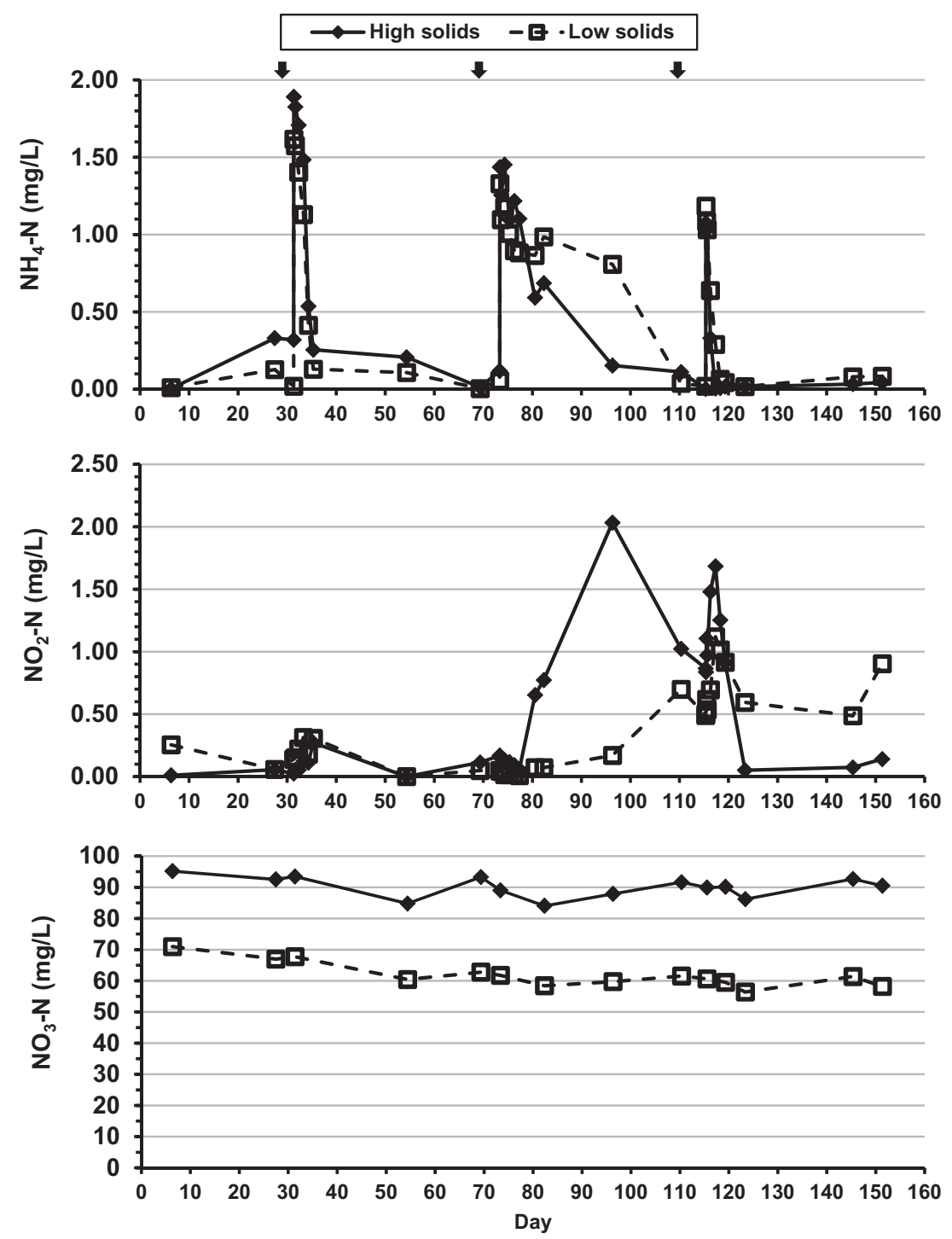

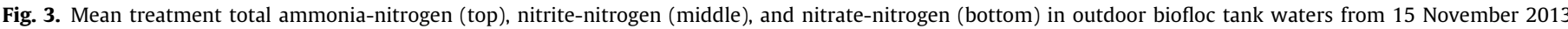

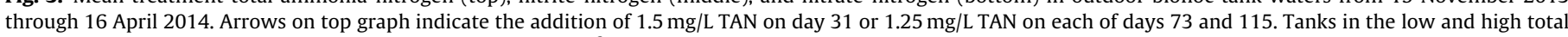
suspended solids treatments were stocked with 7.8 and $8.2 \mathrm{~kg} / \mathrm{m}^{3}$ channel catfish, respectively.

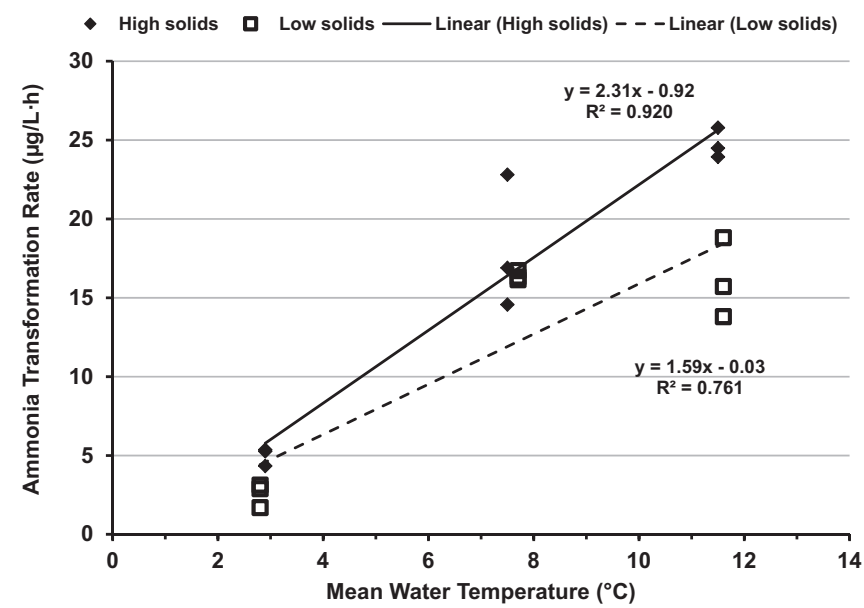

Fig. 4. Slope (absolute value) of ammonia transformation ( $\mu \mathrm{g} / \mathrm{Lh}$ TAN) by treatment following ammonia-nitrogen spike in relation to mean water temperature over the 96-173-h measurement period. observed in the low solids treatment as mean water temperature increased between spike events 2 and 3, whereas in the high solids treatment the ammonia transformation rate continued to increase linearly with increased water temperature. More of the variation in ammonia transformation rate was explained by the linear relationship in the high solids treatment. It should be noted, however, that additional data points at higher temperatures, which was beyond the scope of the present study, are needed if the relationship between ammonia transformation rate and water temperature is to be described fully.

Mean $\mathrm{NO}_{2}-\mathrm{N}$ concentration increased in both treatments following addition of ammonium chloride (Fig. 3). During spike event $1, \mathrm{NO}_{2}-\mathrm{N}$ concentration began to increase $24-48 \mathrm{~h}$ after ammonium chloride addition. Sampling was suspended during the Christmas holiday and at the first sample in January, mean $\mathrm{NO}_{2}-\mathrm{N}$ concentration in both treatments was undetectable analytically. Increases in $\mathrm{NO}_{2}-\mathrm{N}$ concentrations in both treatment following the second spike event were slow and peak concentration lagged the peak TAN concentration by 3 weeks in the high solids treatment and 5 weeks in the low solids treatment, probably because of low water 
temperature. Concentrations did not return to pre-spike levels before ammonium chloride was added for the third time. The spike in $\mathrm{NO}_{2}-\mathrm{N}$ concentration in both treatments occurred about $48 \mathrm{~h}$ after the TAN spike during the third spike event. Eight days after its peak concentration, nitrite concentration declined to less than $0.1 \mathrm{mg} / \mathrm{L} \mathrm{NO}_{2}-\mathrm{N}$ in the high solids treatment, but only to $0.6 \mathrm{mg} / \mathrm{L}$ in the low solids treatment. During the final 30 days of the study, which was when most of the feeding occurred, nitrite concentration remained below $0.2 \mathrm{mg} / \mathrm{L} \mathrm{NO}_{2}-\mathrm{N}$ in the high solids treatment, whereas it varied between 0.5 and $1.0 \mathrm{mg} / \mathrm{L} \mathrm{NO}_{2}-\mathrm{N}$ in the low solids treatment.

Nitrate concentration declined slightly in both treatment over the course of this study (Fig. 3). An increase in $\mathrm{NO}_{3}-\mathrm{N}$ concentration was not detected following any of the TAN spike events. Detection of an increase in $\mathrm{NO}_{3}-\mathrm{N}$ following a TAN spike may have been missed because nitrate was assayed less frequently, but also because of the low concentration of the TAN spike. Bacteria also can consume nitrate and cause it not to accumulate (Choi et al., 2008). Additionally, nitrate likely was used as the nitrogen source by phytoplankton since TAN concentrations generally were low and feed additions were limited. Phytoplankton uptake ammonia preferentially, but utilize nitrate when ammonia concentration is very low or absent (Reynolds, 1984). The low ammonia and high nitrate concentrations present during this study, the observed 5-18\% decline in nitrate concentration, and the high chlorophyll $a$ concentrations support phytoplankton utilization of nitrate.

The data on ammonia and nitrite transformation provide strong evidence of nitrification in the BFT tanks throughout the winter in the absence of sustained TAN input. Others report nitrification occurring at low water temperatures $\left(3-6^{\circ} \mathrm{C}\right)$ in ice-covered lakes (Knowles and Lean, 1987) and in an outdoor aerated submerged biofilm reactor (Choi et al., 2008). However, confirmation that nitrification occurred in the present study would require evidence that alkalinity decreased during the spike events because nitrification consumes bicarbonate (Ebeling et al., 2006). In the absence of such evidence, the data support presumptive nitrification. However, the decrease in total alkalinity and $\mathrm{pH}$ observed over the course of the present experiment supports this conclusion.

Based upon the high chlorophyll a concentration in the low solids treatment at spike event 2 (day 73) and 3 (day 115) (Fig. 2), ammonia uptake by phytoplankton was presumed to be the primary route of ammonia transformation, and nitrification was secondary. Ammonia uptake by phytoplankton and per unit of chlorophyll $a$ was shown to be linearly related to temperature from 5 to $30^{\circ} \mathrm{C}$ and 12 to $30^{\circ} \mathrm{C}$, respectively (Kanda et al., 1985; Cabrita et al., 1999). High algal productivity in catfish ponds results in rapid uptake of ammonia and low aqueous concentrations (Hargreaves and Tucker, 1996). Nitrification likely was the primary ammonia transformation route during the first spike event in the low solids treatment, whereas phytoplankton uptake likely predominated during the third spike event. Despite the $4{ }^{\circ} \mathrm{C}$ increase in water temperature from the second to third spike events, ammonia transformation by presumptive phytoplankton uptake did not appear to increase. In contrast, the ammonia transformation rate increased in the high solids treatment during spike event 3, when nitrification was presumed primarily responsible for ammonia transformation.

\subsection{Catfish production}

At harvest, mean individual weight did not differ significantly between treatments (Table 3 ). There was no significant difference $(P=0.776)$ between high solids treatment initial and final individual weights, but the final individual weight in the low solids treatment was significantly greater $(P=0.046)$ than the initial weight. Fish were fed on 16 day during this study, $80 \%$ of which occurred
Table 3

Treatment least squares mean $( \pm \mathrm{SE})$ initial and final production variables for channel catfish stocked during the winter in outdoor biofloc technology tanks with waters initially containing high and low initial concentrations of total suspended solids (TSS). Tanks were stocked on 15 November 2013 and harvested after 152 days.

\begin{tabular}{lrrrr}
\hline Variable & \multicolumn{2}{l}{ Initial TSS concentration } & \multicolumn{2}{l}{ Pooled } \\
\cline { 2 - 3 } & High & Low & SE & $\operatorname{Pr}>F$ \\
\hline Initial weight $(\mathrm{g} / \mathrm{fish})$ & 611.3 & 560.8 & 16.6 & 0.098 \\
Final weight $(\mathrm{g} / \mathrm{fish})$ & 598.8 & 579.1 & 24.4 & 0.599 \\
Initial biomass $\left(\mathrm{kg} / \mathrm{m}^{3}\right)$ & 8.2 & 7.8 & 0.4 & 0.490 \\
Final biomass $\left(\mathrm{kg} / \mathrm{m}^{3}\right)$ & 7.9 & 7.7 & 0.4 & 0.701 \\
Net fish yield $\left(\mathrm{kg} / \mathrm{m}^{3}\right)$ & -0.3 & -0.1 & 0.1 & 0.146 \\
Survival $(\%)$ & 99.9 & 99.7 & 0.0 & 0.508 \\
\hline
\end{tabular}

from mid-March through 11 April. Daily feed consumption averaged $68.6 \pm 9.5 \mathrm{~g} / \mathrm{m}^{3}$ and $69.9 \pm 9.5 \mathrm{~g} / \mathrm{m}^{3}$ in the low and high solids treatments, respectively, during the last 10 days of feeding. This feed rate typically is observed from late-June through mid-July in the BFT tanks stocked with channel catfish at $12 \mathrm{fish} / \mathrm{m}^{2}$. Total feed consumption did not differ significantly between treatments $(P=0.410)$, averaged $( \pm S E) 0.95 \pm 0.01 \mathrm{~kg} / \mathrm{m}^{3}$ and $0.96 \pm 0.00 \mathrm{~kg} / \mathrm{m}^{3}$ for the low and high solids treatments, respectively, and does not explain the difference between low solids initial and final weights. This difference more likely was the result of sampling error since initial weight was obtained by weighing individually all fish in each tank, whereas final weight was obtained by weighing a random sample of $25 \%$ of fish in each tank.

The capability to biotransform ammonia without a substantial lag once feeding resumes was observed for both treatments in this study. When fish began to feed in mid-March (day 124), mean daily consumption increased rapidly in both treatments from $47 \mathrm{~g} / \mathrm{m}^{3}$ to $69 \mathrm{~g} / \mathrm{m}^{3}$, on average, where it remained for the last 10 feed days of the study. Yet there was no evidence of a sudden increase in TAN concentrations in either treatment; TAN increased from 0.02 to 0.08 and from 0.02 to $0.07 \mathrm{mg} / \mathrm{L} \mathrm{NH}_{4}-\mathrm{N}$ in the low and high solids treatments, respectively. Nitrite decreased from 0.59 to 0.49 in the low solids treatment, and increased from 0.05 to $0.07 \mathrm{mg} / \mathrm{L} \mathrm{NO}_{2}-\mathrm{N}$ in the high solids treatment. Since both treatments were similar, only data from the high solids treatment are presented (Fig. 5).

Although channel catfish will consume feed at water temperatures greater than $7^{\circ} \mathrm{C}$ (Nanninga et al., 2011; Bastola et al., 2012), and feed rate and frequency based on threshold temperatures between 10 and $20^{\circ} \mathrm{C}$ is recommended (Robinson et al., 2001 ), fish in the present study were fed to apparent satiation only after afternoon water temperature exceed $16^{\circ} \mathrm{C}$ for two consecutive days. Estimated daily feed consumption in the present study was $0.9 \%$ of fish biomass and was consistent with daily feed consumption by market-size channel catfish in other winter feeding studies (Nanninga et al., 2011; Bastola et al., 2012).

Catfish survival throughout the winter was high, did not differ significantly between treatments, and averaged $99.8 \%$ (Table 3). A total of three fish died: one in a high solids tank, and one in each of two low solids tanks. At harvest, fish appeared robust and healthy. Survival of market-size channel catfish over the winter in some studies exceeded 90\% (Lovell and Sirikul, 1974; Tackett et al., 1987; Tidwell and Mims, 1991), whereas in other studies survival ranged from 64 to 84\% (Nanninga et al., 2011; Bastola et al., 2012). Mean final biomass and net fish yield did not differ significantly between treatments (Table 3). Net fish yields were 1-4\% less than initial fish biomasses. Other researchers report negative net yield (losses of $2-10 \%)$ for over-wintered channel catfish, often when fish are not fed (Lovell and Sirikul, 1974; Tidwell and Mims, 1991; Nanninga et al., 2011; Bastola et al., 2012). It is possible that net yields in the present study would have been positive had feeding been initiated at a lower threshold temperature (Tidwell and Mims, 1991; Robinson et al., 2001). 


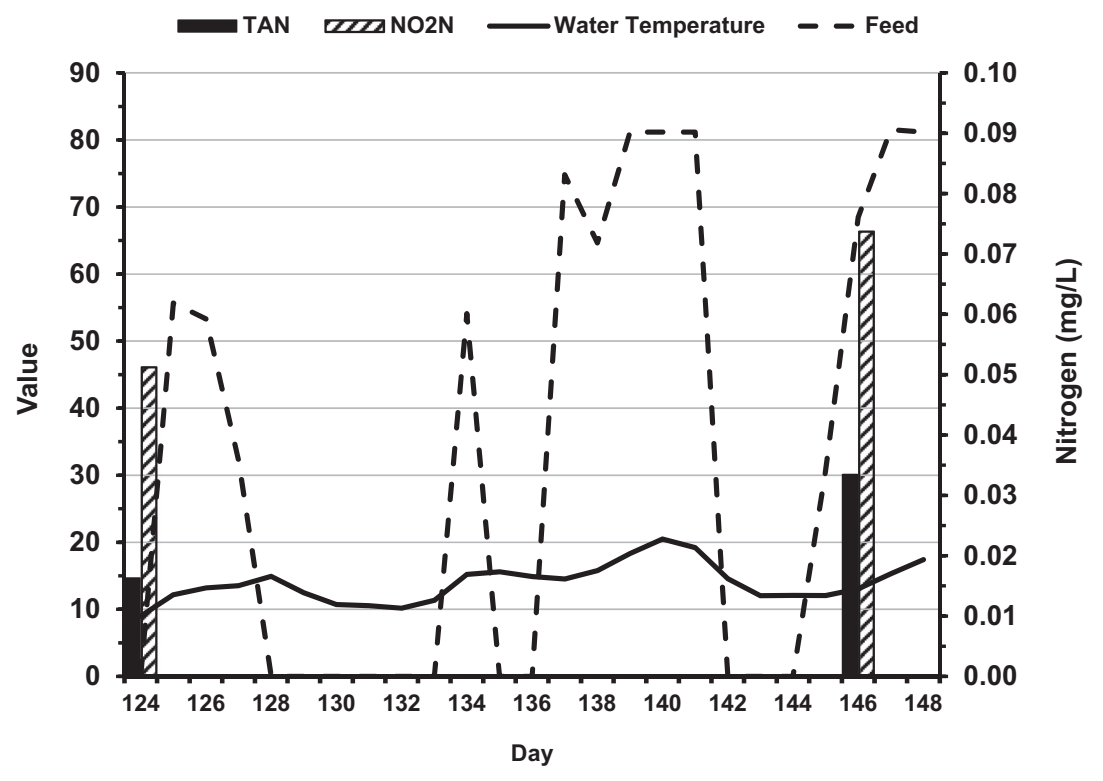

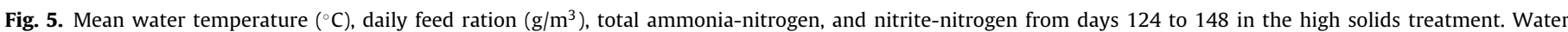
temperature and daily feed correspond to the left-hand vertical axis, and TAN and nitrite correspond to the right-hand vertical axis.

\subsection{Summary}

In summary, BFT water with a low initial TSS concentration transitioned to a phytoplankton dominated system whereas water with a high initial TSS concentration remained a bacterially dominated system. This divergence resulted in changes in water quality variables over the course of the experiment that differed between treatments. The ability of the biofloc system to biotransform ammonia-nitrogen was retained at low winter water temperatures and in the absence of sustained TAN input in both treatments, although this really is of minor importance because fish are not consuming feed and excreting ammonia. What is important, though, is that the capability to biotransform ammonia without a substantial lag is retained once feeding resumes. High biomasses of market-size channel catfish were maintained through the winter with high survival and in good condition in both treatments. Net yield was negative in both treatments, but might have been positive had feeding begun at a threshold temperature of $10^{\circ} \mathrm{C}$ instead of $16^{\circ} \mathrm{C}$. Having an active biofloc in the spring obviates the start-up time required to establish a new, fully functional biofloc and the associated TAN and nitrite spikes. Of course, an economic analysis would be necessary to determine the costs and economic viability of maintaining the biofloc through the winter.

\section{Acknowledgments}

The technical assistance of Greg O'Neal and Paxton Harper is greatly appreciated. The assistance of Robert Dallas II, Dallas Group of America, in procuring the ammonium chloride is greatly appreciated. This study was funded by the USDA/ARS under project number 6225-31630-006-00D. No source of funding external to the author institution was used for this study. The author does not have any conflict of interest. Mention of trade names or commercial products in this article is solely for the purpose of providing specific information and does not imply recommendation or endorsement by the U.S. Department of Agriculture. USDA is an equal opportunity provider and employer.

\section{References}

Avnimelech, Y., 1999. Carbon/nitrogen ratios as a control element in aquaculture systems. Aquaculture 176, 227-235.
Bastola, U., Engle, C.R., Haukenes, A., Freeman, D., 2012. The costs and effects of alternative winter feeding strategies for channel catfish Ictalurus punctatus in multiple-batch production. J. Appl. Aquac. 24, 283-298.

Burford, M.A., Thompson, P.J., McIntosh, R.P., Bauman, R.H., Pearson, D.C. 2004. The contribution of flocculated material to shrimp (Litopenaeus vannamei) nutrition in a high-intensity, zero-exchange system. Aquaculture 232, 525-537.

Burtle, G.J., Newton, G.L., 1993. Winter feeding frequency for channel catfish in cages. Progress. Fish-Cult. 55, 137-139.

Cabrita, M.T., Catarino, F., Slawyk, G., 1999. Interactions of light, temperature and inorganic nitrogen in controlling planktonic nitrogen utilisation in the Tagus estuary. Aquat. Ecol. 33, 251-261.

Choi, Y., Johnson, K., Hayes, D., Xu, H., 2008. Pilot-scale aerated submerged biofilm reactor for organics removal and nitrification at cold temperatures. Water Environ. Res. 80, 292-297.

Eaton, A.D., Clesceri, L.S., Rice, E.W., Greenberg A.E., 2005. Standard Methods for the Examination of Water and Wastewater, 21st edition. American Public Health Association, Washington.

Ebeling, J.M., Timmons, M.B., Bisogni, J.J., 2006. Engineering analysis of the stoichiometry of photoautotrophic, autotrophic, and heterotrophic removal of ammonia-nitrogen in aquaculture systems. Aquaculture 257, 346-358.

Genfa, Z., Dasgupta, P.K., 1989. Fluorometric measurement of aqueous ammonia ion in a flow injection system. Anal. Chem. 61, 408-412.

Green, B.W., 2010. Effect of channel catfish stocking rate on yield and water quality in an intensive, mixed suspended-growth production system. N. Am. J. Aquac. 72, 97-106.

Green, B.W., Schrader, K.K., Perschbacher, P.W., 2014. Effect of stocking biomass on solids, phytoplankton communities, common off-flavors, and production parameters in a channel catfish biofloc technology production system. Aquac. Res. 45, 1442-1458.

Hargreaves, J.A., 2006. Photosynthetic suspended-growth systems in aquaculture Aquac. Eng. 34, 344-363.

Hargreaves, J.A., Kucuk, S., 2001. Effects of diel un-ionized ammonia fluctuation on juvenile hybrid striped bass, channel catfish, and blue tilapia. Aquaculture 195, 163-181.

Hargreaves, J.A., Tucker, C.S., 1996. Evidence for control of water quality in channel catfish Ictalurus punctatus ponds by phytoplankton biomass and sediment oxygenation. J. World Aquac. Soc. 27, 21-29.

Kanda, J., Saino, T., Hattori, A., 1985. Nitrogen uptake by natural populations of phytoplankton and primary production in the Pacific Ocean: regional variability of uptake capacity. Limnol. Oceanogr. 30, 987-999.

Knowles, R., Lean, D.R.S., 1987. Nitrification: a significant cause of oxygen depletion under winter ice. Can. J. Fish. Aquat. Sci. 44, 743-749.

Li, M.H., Robinson, E.H., Bosworth, B.G., Oberle, D.F., Lucas, P.M., 2009. Evaluation of various feeding regimens in a multiple-batch cropping system of channel catfish production. N. Am. J. Aquac. 71, 210-215.

Littell, R.C., Milliken, G.A., Stroup, W.W., Wolfinger, R.D., Schabenberger, O., 2006 SAS for Mixed Models, 2nd edition. SAS Institute, Inc., Cary.

Lloyd, S.W., Tucker, C.S., 1988. Comparison of three solvent systems for extraction of chlorophyll a from fish pond phytoplankton communities. J. World Aquac. Soc. 19, 36-40.

Lovell, R.T., Sirikul, B., 1974. Winter feeding of channel catfish. Proc. Ann. Conf. Southeast Assoc. Game Fish Comm. 28, 208-216. 
Nanninga, A.S., Engle, C.R., Stone, N., Goodwin, A.E., 2011. Effects of winter feeding of channel catfish on production in multibatch system. N. Am. J. Aquac. 73, 60-67.

Ray, A.J., Lewis, B.L., Browdy, C.L., Leffler, J.W., 2010. Suspended solids removal to improve shrimp (Litopenaeus vannamei) production and an evaluation of a plant-based feed in minimal-exchange, superintensive culture systems. Aquaculture 299, 89-98.

Reynolds, C.S., 1984. The Ecology of Freshwater Phytoplankton. Cambridge University Press, Cambridge.

Robinson, E.H., Li, H.M., 2008. Effects of feeding diets with and without fish meal on production of channel catfish, Ictalurus punctatus, stocked at varying densities. J. Appl. Aquac. 20, 233-242.
Robinson, E.H., Li, H.M., Manning, B.B., 2001. Practical Guide to Nutrition, Feeds, and Feeding Practices. Mississippi Agricultural and Forestry Experiment Station Bulletin 1113. Mississippi State University, Mississippi State.

Schrader, K.K., Green, B.W., Perschbacher, P.W., 2011. Development of phytoplankton communities and common off-flavors in a biofloc technology system used for the culture of channel catfish (Ictalurus punctatus). Aquac. Eng. 45, 118-126.

Tidwell, J.H., Mims, S.D., 1991. Effects of density and feeding regime on overwintering of channel catfish. J. Appl. Aquac. 1, 103-111.

Tackett, D.L., Carter, R.R., Allen, K.O., 1987. Winter feeding of channel catfish based on maximum air temperature. Progress. Fish-Cult. 49, 290-292. 